\title{
Incentives for Cost Reducing Innovations Under Quantitative Import Restraints
}

\author{
Célia COSTA CABRAL, \\ Praveen KUJAL, Emmanuel PETRAKIS*
}

\begin{abstract}
The effect of trade quotas on firms' incentive to invest in cost-reducing $R \& D$ is studied in a two-stage price-setting duopoly game. A domestic and a foreign firm first choose $R \& D$ levels and then set the prices of their differentiated products in the domestic market. With a quota imposed at, or close to, the free-trade level of imports, the domestic firm faces less competition than under free-trade and invests less in R\&D. Contrarily, the constrained foreign firm invests more in $R \& D$ as the negative strategic effect of a reduction in its cost is now absent. These results differ partially from the Cournot duopoly case in which $R \& D$ expenditures are lower for both the firms. As the quota becomes more restrictive, the domestic firm increases and the foreign firm decreases its expenditures on R\&D. Domestic welfare is always higher under free-trade than under any quota regardless of the degree of product substitutability.
\end{abstract}

\section{Incitations à l'innovation afin de réduire les coûts de production sous des restrictions quantitatives à l'importation.}

RÉSUMÉ. - Dans cet article, une firme nationale et une firme étrangère choisissent leurs niveaux de R\&D dans un premier temps, puis fixent les prix de leurs produits différenciés sur le marché national. Si le quota imposé est égal ou est suffisamment proche du niveau des importations sous libre échange, la firme nationale investit moins en R\&D. La firme étrangère contrainte investit plus, vu que l'effet stratégique négatif de la réduction des coûts par la R\&D disparaît. On montre aussi que le niveau de bien-être national est toujours plus élevé sous libre échange indépendamment du degré de substituabilité des produits.

\footnotetext{
* C. Costa Cabral: Universidade Nova de Lisboa; P. Kuj al: Universidad Carlos III de Madrid; E. Petrakis: Universidad Carlos III de Madrid. The authors acknowledge the comments received from Peter Neary and other participants at the CEPR ERWIT meeting in Thessaloniki, 1995, the J ornadas de Economía Industrial in Madrid, 1995, the ADRES conference at Strasbourg, J une 1996, FEDEA and two anonymous referees. Kujal and Petrakis acknowledge support from the DGICYT grant PB95-287 and financial support from the grant Acción Integrada Hispano-Portuguesa 1996, 29 B. Cabral acknowledges financial support from the grant Ações Integradas LusoEspanholas E-63/96.
} 


\section{Introduction}

The use of trade policies aimed at protecting domestic industries is sometimes justified using the "infant industry" argument. Those in favor of this type of policy argue that trade protection is industry-promoting in the sense that domestic producers, sheltered from foreign competition, can choose long-run strategic variables ${ }^{1}$, that ensure long-run gains in profitability ${ }^{2}$. Investment in cost-reducing innovation is one of such strategic variables. Protectionist measures have been shown to affect this variable choice in the "wrong" direction, as shown by REITZES [1991].

REITZES [1991] looks at the impact of quotas (and tariffs) on strategic R\&D behavior. Using a two-stage Cournot duopoly game, where firms initially choose R\&D levels and subsequently compete in quantities, Reitzes shows that both the domestic and the foreign firm choose lower levels of cost-reducing $R \& D$ when a quota is set at the free trade level of production than under free trade. The reason for the decline in $R \& D$ is that, in the presence of a quota, the strategic value of $R \& D$ vanishes. With a quota, the domestic firm becomes a monopolist on the residual demand, and thus chooses its cost-minimizing level of R\&D expenditures. The foreign firm, constrained by the quantity it may sell, will also have less incentives to invest in cost reduction. Note that, although domestic productive efficiency deteriorates as a consequence of the quota, its relative (to the foreign country) efficiency does not necessarily become worse. With the exception of REITZES [1991], very little has been written on the effects of this type of protection on firms' investment in cost-reducing assets.

In this paper, the objective is to study whether REITZES' [1991] results still hold under price competition, since it is known that price competition produces effects on incentives to innovate which are usually the reverse from Cournot competition. For instance, with respect to the well known BRANDER and SPENCER [1985] result where they show that in a Cournot model the domestic government should subsidize exports EATON and GROSSMAN [1986] show that changing the assumption to price competition results in the domestic government taxing exports. Further, BESTER and PETRAKIS [1993] show that if the domestic and the foreign goods are relatively close substitutes, Cournot competition provides weaker incentives to invest in cost-reducing R\&D than Bertrand competition, and vice versa for high substitutability among goods. Note, that in all these papers changing the choice variable results in a complete reversal of the outcomes.

1. Examples of strategic variables are quality, $R \& D$ investment, expenditure on innovation etc.

2. This is the political economy argument towards infant industry protection. The economic argument for industry protection refers to spillovers. Either of these two arguments may be behind protectionist practices. In this paper, we are concerned with the former argument. The case of India, where industrialists wholeheartedly supported the erection of import barriers, leading to the erection of substantial regulatory barriers, is an example of the desire to ensure the 'growth' of domestic industry through protection (KuJAL, 1996). 
We show that in a price setting game, when a quota is set at the free trade level, the domestic firm lowers and the foreign firm increases its expenditures on R\&D. This result (unlike the complete reversal obtained in other papers) is a partial reversal from REITZES' [1991], where both firms invest less in R\&D. Under price competition, foreign investment in $R \& D$ has a negative indirect (strategic) effect on foreign firm's profits: higher foreign firm's investment in R\&D makes the domestic firm lower its price, which in turn results in lower price and profits for the foreign firm. This makes the foreign firm "underinvest" in R\&D. With the introduction of a quota, the negative effect disappears for the foreign firm and investment in R\&D increases necessarily for the constrained case. Under Cournot competition, the strategic effect has just the opposite sign, which explains the reversal of the results for the foreign firm. Contrarily (as in REITZES [1991]), as the domestic firm faces less competition from the foreign firm after the imposition of the quota it underinvests in R\&D. As a consequence, under price competition the domestic industry's absolute and relative productive efficiency necessarily decreases in the presence of a quota. Then the infant industry argument cannot be even partially justified as in Reitzes ' case.

We further show that these qualitative results depend also on how restrictive the quota is. As the quota becomes more restrictive the domestic firm increases and the foreign firm decreases its expenditures on R\&D. For a restrictive enough quota, the domestic firm's level of $R \& D$ expenditure may exceed the free trade level, and the foreign firm's may decrease relatively to the free trade case. These results are important since, unlike suggested by the infant industry protection argument, strategic variable choices may change in the "wrong" direction: if less R\&D takes place domestically while the foreign firm increases its own effort to reduce costs, the relative domestic production cost increases. This also renders less likely that protection will be just temporary, if the domestic firm is to survive future competition. Domestic R\&D efforts may increase, but this can only be achieved if the quota is restrictive enough.

Finally, we show that domestic welfare is always higher under free trade independently of the degree of product differentiation. This result constitutes a strong argument against this type of protectionist policies. However, if the quota is to be imposed, the right level of quota will depend on the degree of product differentiation. If the goods are close enough substitutes the domestic government may want to completely shut the foreign firm out of the domestic market. If the goods are significantly differentiated, then the right level of the quota will be at the free-trade level of production. This may explain why in many developing countries, close substitutes to domestic production were completely shut out of the market.

The paper is organized as follows. In Section 2 the model is presented and equilibrium under free trade determined. In Section 3, equilibrium after the imposition of an import quota is determined for a sequential move price setting game. Section 4 presents the welfare analysis and Section 5 concludes. 


\section{The Model under Free Trade}

There are two firms, one domestic and one foreign. Firms produce goods which are imperfect substitutes and sell their production in the domestic market only ${ }^{3}$. Firms face the following (symmetric) demand functions ${ }^{4}$ :

$$
x_{i}=\frac{1}{1-\gamma^{2}}\left[a(1-\gamma)-p_{i}+\gamma p_{j}\right], \quad i, j=1,2 .
$$

$\gamma$ measures the degree of product differentiation. As $\gamma$ goes to zero, each firm becomes a local monopolist. When $\gamma$ goes to one, firms' goods are almost perfect substitutes. To avoid corner solutions, we shall assume that $\gamma \leq 0.827891$. The domestic firm is denoted by $i=1$, and the foreign firm by $i=2$. Both firms have initially the same unit production costs, $c$. Firms can invest in $R \& D$ in order to reduce their unit cost. In particular, by investing $\frac{\Delta_{i}^{2}}{2}$ firm $i$ will reduce its cost by $\Delta_{i}$.

Firms play a two-stage game. In stage one, firms simultaneously decide on how much to invest in cost-reducing R\&D. In stage two, given the (reduced) unit cost, firms decide simultaneously on which price to set. It should be noted that R\&D has a commitment value in this context. Firms can use R\&D strategically to improve their position in the subsequent market competition game. The problem is solved recursively for the equilibrium outcomes, i.e., we restrict our attention to the subgame perfect equilibria.

\section{(i) the market competition stage}

Firm $i$ chooses $p_{i}$ to maximize profits:

$$
\max \left[p_{i}-\left(c-\Delta_{i}\right)\right] x_{i}\left(p_{i}, p_{j}\right) .
$$

$p_{j}$ and $\Delta_{i}$ are taken as given. This defines each firm's reaction function:

$$
p_{i}=b_{i}\left(p_{j} ; \Delta_{i}\right) \equiv \frac{a(1-\gamma)+c-\Delta_{i}+\gamma p_{j}}{2} .
$$

In figure 1 , firms' reaction functions under free trade are depicted. The dashed line $b_{i}\left(p_{j}\right)$ represents the price firm $i$ will choose to set given firm $j$ 's price $p_{j}$.

3. This approach to modelling the effects of trade policies is standard to the literature. Of course, the issue of retaliation is important in trade policy (we would like to thank one of the referees for pointing this out). However, conditions under which quantity restrictions are only imposed by the home country has many parallels in real world situations. For example, VERs by definition are not retaliatory in nature and have been the accepted mode of quantity controls both in the U.S. and the E.U in their trade with Japan and South Korea. Given that in the presence of quantity restrictions trade between countries co-exists provides us with ample evidence that justifies the use of only one active government.

4. These are the demand functions of a representative consumer with utility $u\left(x_{i}, x_{j}\right)=$ $a\left(x_{i}+x_{j}\right)-\left(x_{i}^{2}+x_{j}^{2}+2 \gamma x_{i} x_{j}\right) / 2+m$ with $m$ representing money, following DiXIT (1979). Resulting inverse demand is $p_{i}=a-x_{i}-\gamma x_{j}$. 
Then equilibrium prices and profits are:

$$
p_{i}=\frac{1}{4-\gamma^{2}}\left\{[a(1-\gamma)+c](2+\gamma)-2 \Delta_{i}-\gamma \Delta_{j}\right\},
$$

and

$$
\pi_{i}=\frac{\left(p_{i}-c+\Delta_{i}\right)^{2}}{1-\gamma^{2}}-\frac{\Delta_{i}^{2}}{2} .
$$

FIGURE 1

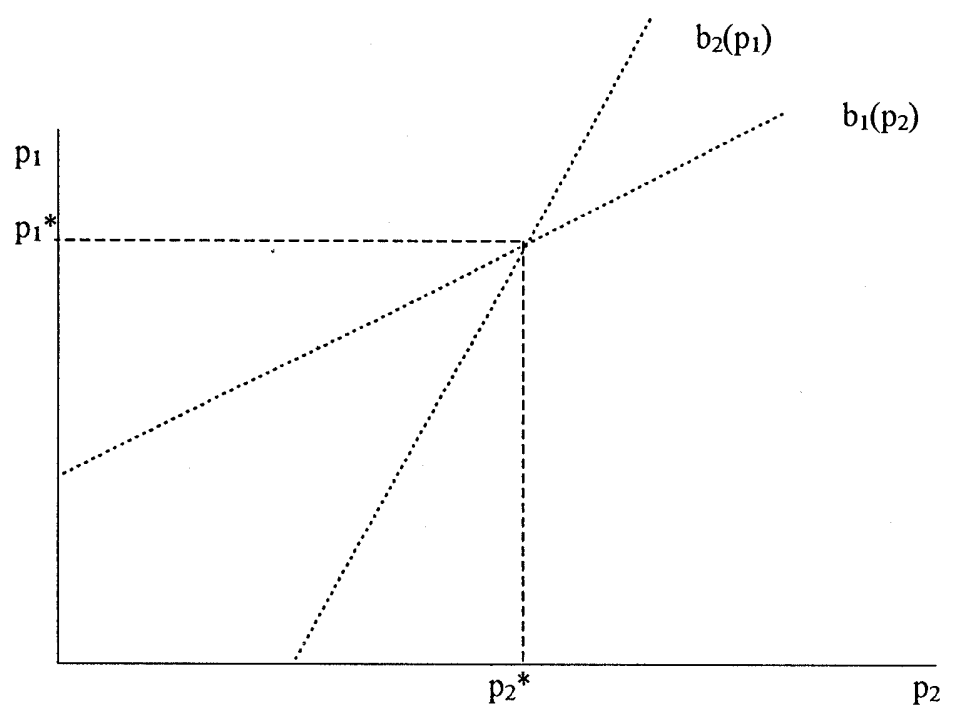

(ii) the $R \& D$ stage

Firm $i$, given $\Delta_{j}$, chooses $\Delta_{i}$ to maximize its profits (defined in (4). From the first-order conditions and symmetry we obtain optimal R\&D spending, output and price for each firm:

$$
\Delta^{*}=\frac{2\left(2-\gamma^{2}\right)}{D(\gamma)}(a-c)
$$

$$
x^{*}=\frac{\left(4-\gamma^{2}\right)}{2\left(2-\gamma^{2}\right)} \Delta^{*},
$$

$$
p^{*}=\frac{1}{2-\gamma}\left[a(1-\gamma)+c-\Delta^{*}\right]
$$


Firms' profits are then given by

$$
\pi^{*}=\frac{8-16 \gamma^{2}+7 \gamma^{4}-\gamma^{6}}{D(\gamma)^{2}}(a-c)^{2}
$$

where $D(\gamma)=(1+\gamma)(2-\gamma)\left(4-\gamma^{2}\right)-2\left(2-\gamma^{2}\right)$.

Note, that under price competition a firm has less incentives to invest in cost-reducing $R \& D$ than under a pure cost-minimizing strategy. There is a negative strategic effect when firms compete in prices. As a response to firm i's reduction of unit cost, its rival decreases its price (see (3)), thus shifting-in $i$ 's demand function. Firm $i$ has now to reduce its price in order to sell the same output. By lowering its R\&D expenditures beyond the cost-minimizing level, a firm can commit to softer competition in the subsequent market game.

\section{Equilibrium under Import Quotas}

In this section we assume that the domestic government precommits to a given quota level $\bar{x}$ (or, the foreign government precommits to a level of VER) before the firms decide how much to invest in R\&D. For illustrative purposes we shall concentrate on the analysis of the case where a quota is set at the free-trade level of imports. A similar reasoning applies to the case of more restrictive quotas. Henceforth, firm 2 (the foreign firm) is assumed to be restricted to sell no more than $\bar{x}$ units, with $\bar{x}$ being set at the free-trade level of imports as defined by (6).

\subsection{The Best Response Functions}

As shown by KRISHNA [1989], the imposition of quantity restrictions alters firms' best response functions in the market competition stage ${ }^{5}$. Let us define $f\left(p_{1}, \bar{x}\right)$ as the foreign firm's price level that yields a demand for its good just equal to $\bar{x}$. Clearly, this is a function of the price selected by the domestic firm $p_{1}$. In figure $2, f\left(p_{1}, \bar{x}\right)$ is represented by the dashed line between $b_{2}\left(p_{1}\right)$ and $b_{1}\left(p_{2}\right)$. Since the quota is set at the free-trade equilibrium level of production, this line has to go through the free-trade equilibrium point (the point where the original reaction functions $b_{i}\left(p_{j}\right)$ intersect). Above $f\left(p_{1}, \bar{x}\right)$, the foreign firm is bound by the restriction while below it the restriction is not binding. Firm 2's best response is not altered from the free-trade case if $p_{1}<p^{*}$ since optimal pricing decisions do not involve firm 2 's production exceeding $\bar{x}$ : the domestic firm's price is low

5. The derivation of the best response functions that follows draws on KRISHNA (1989). 
enough for firm 2's production to be below its free trade level, now the quota level. However, if the domestic firm's price exceeds the free-trade equilibrium price, i.e., if $p_{1}>p^{*}$, then, in the absence of a quota, the foreign firm would like to produce more than $\bar{x}$. But, that is no longer possible. The foreign firm's best response is then to select a price high enough so that its demand is just equal to the quota level $\bar{x}$. In this case, the best response function coincides with the $f\left(p_{1}, \bar{x}\right)$ line. Firm 2 's best response function is depicted in figure 2, given by the kinked full line and is defined by:

$$
\hat{b}_{2}\left(p_{1}, \bar{x}\right)=\left\{\begin{array}{cl}
b_{2}\left(p_{1}\right) & \text { if } p_{1} \leq p^{*} \\
f\left(p_{1}, \bar{x}\right) & \text { if } p_{1}>p^{*}
\end{array}\right.
$$

Using (1) this can be written as:

$\hat{b}_{2}\left(p_{1}, \bar{x}\right)=\max \left\{\frac{a(1-\gamma)+c-\Delta_{2}+\gamma p_{1}}{2}, a(1-\gamma)-\left(1-\gamma^{2}\right) \bar{x}+\gamma p_{1}\right\}$.

FIGURE 2

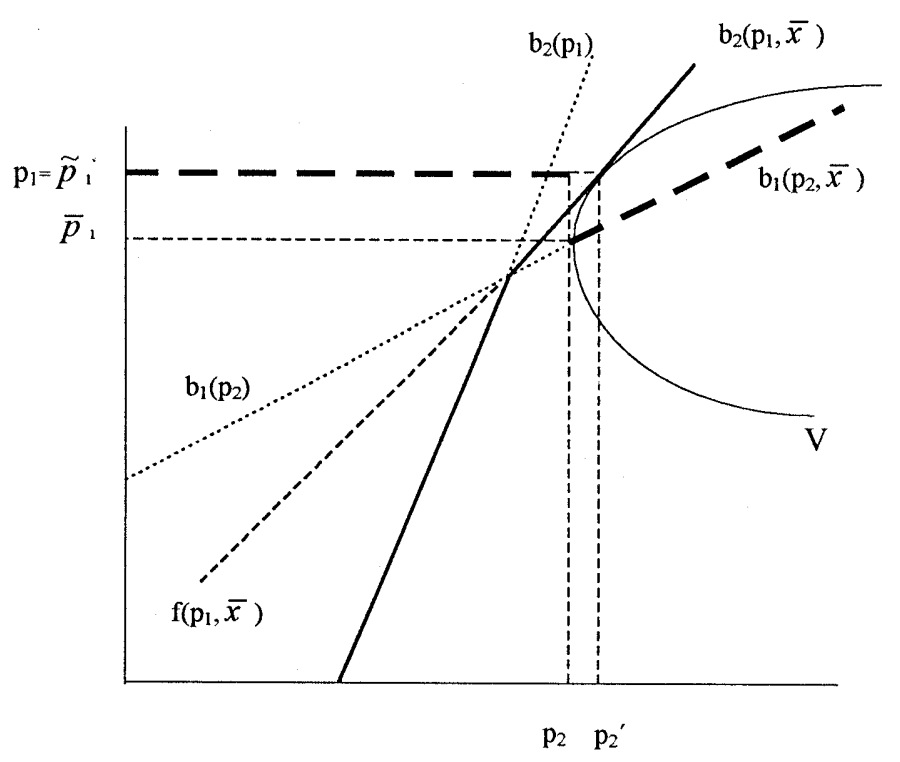

Let us now turn to the determination of the domestic firm's best response function. Let us define $F\left(p_{2}, \bar{x}\right)$ as the function that determines the domestic price level which, given $p_{2}$, yields a demand level for the foreign product exactly equal to $\bar{x}$. Graphically, $F\left(p_{2}, \bar{x}\right)$ coincides with $f\left(p_{1}, \bar{x}\right)$, since, by definition one function is the inverse of the other. When firm 2 is bound by the quota level, then domestic firm's demand depends only on its own price: $p_{1}=a-x_{1}-\gamma \bar{x}$. Hence, above $F\left(p_{2}, \bar{x}\right)$, the domestic firm's isoprofit curves are horizontal and there is a unique price, $\bar{p}_{1}$, which maximizes 
its profits. In this case, some consumers are rationed by the (low-priced) foreign firm. Assume the following rationing rule: consumers lucky enough to buy the foreign firm's good, are able to resell it costlessly in the market. This situation is equivalent to the foreign firm selecting a best reply to $\bar{p}_{1}$. This, in turn, guarantees a profit level of $V$ to the domestic firm, the same as the profits that a Stackelberg leader, who makes the quota bind on the foreign firm, can achieve.

Below $F\left(p_{2}, \bar{x}\right)$, the domestic firm's isoprofit curves remain the same as under free-trade. As a result, isoprofit curves are kinked along $F\left(p_{2}, \bar{x}\right)$, and moreover they are not convex anymore. If the foreign firm's price is higher than $p_{2}^{\prime}$, then the domestic firm can reach a profit level higher than $\mathrm{V}$ by choosing not to make the foreign firm bound by the quota. If, however, the foreign firm's price is lower than $p_{2}^{\prime}$, the domestic firm can always guarantee profits of $V$ by choosing $\bar{p}_{1}$. Firm 1's best response function is given by the two dark dashed lines in figure 2 and is defined by $\hat{b}_{1}\left(p_{2}, \bar{x}\right)$ :

$$
p_{1}=\hat{b}_{1}\left(p_{2}, \bar{x}\right)=\left\{\begin{array}{cc}
\bar{p}_{1} & \text { if } p_{2} \leq p_{2}^{\prime} \\
b_{1}\left(p_{2}\right) & \text { if } p_{2} \geq p_{2}^{\prime}
\end{array}\right.
$$

It should be noted that firm 1's best response function is not continuous and that it assumes two values when $p_{2}=p_{2}^{\prime}$ (the same profit level $V$ can be reached charging either $\bar{p}_{1}$ or $\tilde{p}_{1}$ ).

\subsection{Equilibrium with Sequential Moves}

When firms choose prices simultaneously, there is a unique equilibrium in mixed strategies in the market competition game where the foreign firm chooses $p_{2}^{\prime}$ and the domestic firm randomizes over $\left(\bar{p}_{1}, \tilde{p}_{1}\right)$, (see KRISHNA [1989]). In this equilibrium the domestic firm always obtains profits of $V$ : the profit level that a domestic firm could attain as a Stackelberg leader that makes the quota bind on the foreign firm. The domestic firm is, thus, indifferent between being a price leader or choosing its price simultaneously with its rival. The foreign firm, playing simultaneously, obtains strictly lower profits than the Stackelberg follower's profits ${ }^{6}$.

Thus, we can imagine that there exist two stages, 1 and 2, before the good is sold in the market. Since by acting as a Stackelberg follower in the price competition game it is guaranteed higher profits the foreign firm will let the domestic firm set its price before it chooses its own. Our justification for this sequence of moves is along the lines of the existing literature on

6. This is true since a Stackelberg follower (foreign) firm sets a higher price than in the simultaneous move game $\left(\hat{p}_{2}>p_{2}^{\prime}\right)$ and, moreover, it always sells at the quota level $\bar{x}$. As we saw, under simultaneous choice of prices, the foreign firm sells at the quota level only when the domestic firm sets its price at $\bar{p}_{1}$, while it sells less than $\bar{x}$ when the domestic price is $\tilde{p}_{1}$, in the mixed strategy equilibrium. Thus, the foreign firm attains higher profits whenever it acts as a Stackelberg follower. 
the endogeniety of moves. In fact, Furth and Kovenock [1993] ${ }^{7}$ use similar arguments to ours to show endogeniety of moves in a much more general setting. They also show that precisely in the structure of the Krishna paper mentioned above the endogenous outcome of player moves is in-fact along the lines of our argument. That is, the domestic firm emerges as the Stackelberg leader and the foreign firm the Stackelberg follower.

The imposition of the quota thus changes the timing of player moves. We, therefore, assume that the firms choose their prices sequentially with the domestic firm being the Stackelberg leader and the foreign firm the Stackelberg follower in the price setting game (as in HARRIS [1985]) ${ }^{8}$.

So far we have only treated the case of a quota imposed at the free-trade level of imports. A similar analysis applies to more restrictive quotas. In what follows, we take as given that the imposition of any quota alters the sequence of price choices in the market game.

The game becomes a 3-stage game. In the first stage, both firms select R\&D levels. In the second stage, the domestic firm sets its price, and in the third stage, the foreign firm selects its price.

(i) stage-3

Given $\Delta_{1}, \Delta_{2}$ and $p_{1}$, the foreign firm sells $\bar{x}$, and charges the market clearing price:

$$
p_{2}=f\left(p_{1}, \bar{x}\right)=a(1-\gamma)-\left(1-\gamma^{2}\right) \bar{x}+\gamma p_{1}
$$

\section{(ii) stage-2}

The domestic firm is now a constrained monopolist facing a residual demand $x_{1}=D_{R}\left(p_{1}\right)=a-\gamma \bar{x}-p_{1}$. Then its profit maximizing price and output levels are:

$$
\begin{aligned}
& p_{1}=\frac{a+c-\gamma \bar{x}-\Delta_{1}}{2}, \\
& x_{1}=\frac{a-c-\gamma \bar{x}+\Delta_{1}}{2} .
\end{aligned}
$$

Resulting profits are

$$
\pi_{1}=\frac{\left(a-c-\gamma \bar{x}+\Delta_{1}\right)^{2}}{4}-\frac{\Delta_{1}^{2}}{2} .
$$

It should be noted that the domestic price and profits do not depend on $\Delta_{2}$. Note, also that, when the quota is binding on the foreign firm, R\&D

7. Also see Corneo (1995), DeneCKere and Kovenock (1992) and Syropoulos (1996).

8. Note, that qualitatively similar results hold even when firms set their prices simultaneously. For the reasons mentioned above and given that mixed strategies in the simultaneous move game significantly complicate the analysis, we have opted for exposing the sequential move game only. The analytical treatment of the Bertrand game is available upon request. 
has no strategic value for the domestic firm. Hence, it will simply choose the cost-minimizing level of $\mathrm{R} \& \mathrm{D}$, acting as a constrained monopolist.

Substituting (10) into (9), we obtain the foreign firm's price and profits:

$$
\begin{gathered}
p_{2}=\frac{a(2-\gamma)-\left(2-\gamma^{2}\right) \bar{x}+\left(c-\Delta_{1}\right) \gamma}{2} \\
\pi_{2}=\left\{\left[\frac{a(2-\gamma)-\left(2-\gamma^{2}\right) \bar{x}+\left(c-\Delta_{1}\right) \gamma}{2}\right]-c+\Delta_{2}\right\} \bar{x}-\frac{\Delta_{2}^{2}}{2}
\end{gathered}
$$

Note that, whatever the reduction of its unit cost, the foreign firm always sells at the quota level. As a result, its marginal revenue from a reduction in its unit cost is simply equal to the quota level itself. Hence, the imposition of the quota removes the negative strategic effect which was present under free-trade price-competition.

(iii) stage-1

Maximizing profits as defined by (12) and (14), and solving the firstorder conditions, we get the optimal R\&D levels for the domestic and the foreign firms:

$$
\begin{gathered}
\widetilde{\Delta}_{1}=a-c-\gamma \bar{x} \\
\widetilde{\Delta}_{2}=\bar{x}
\end{gathered}
$$

Domestic R\&D decreases with the quota level. As the quota becomes more restrictive on the foreign firm, the domestic firm's residual demand increases and thus also the profitability of a reduction in its unit cost. Contrarily, foreign $\mathrm{R} \& \mathrm{D}$ levels increase with the quota level and in a oneto-one relation. This is because, as we saw, the foreign firm's marginal revenue of a reduction in unit cost is equal to the quota, while the marginal cost is $\Delta_{2}$.

Figure 3 depicts $\widetilde{\Delta}_{i}$ as a function of the level of the quota $\bar{x}$ imposed on the foreign firm.

FIGURE 3

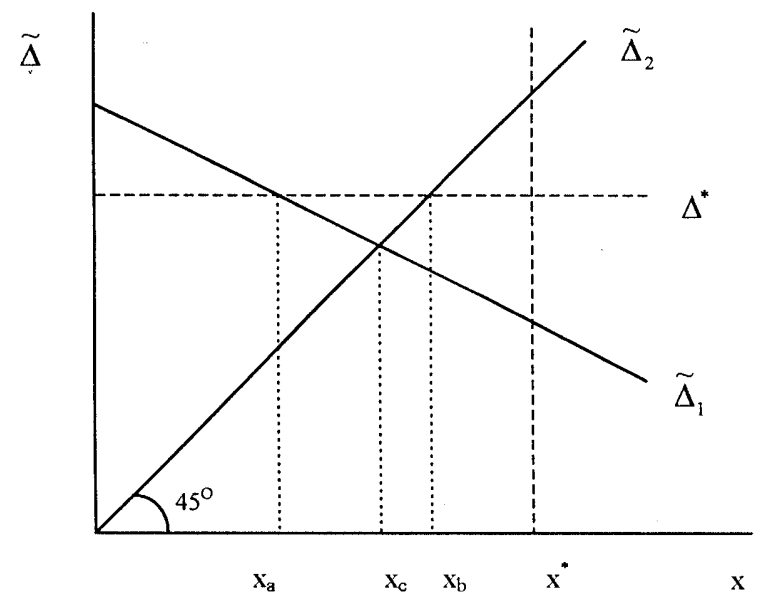


Finally, prices, quantities and profits can now be determined:

$$
\begin{gathered}
\hat{p}_{1}=c \\
\hat{p}_{2}=a(1-\gamma)-\bar{x}\left(1-\gamma^{2}\right)+c \gamma \\
\hat{x}_{1}=a-c-\gamma \bar{x} \\
\hat{x}_{2}=\bar{x} \\
\hat{\pi}_{1}=\frac{(a-c-\gamma \bar{x})^{2}}{2} \\
\hat{\pi}_{2}=\frac{\bar{x}}{2}\left[2(a-c)(1-\gamma)+\bar{x}\left(2 \gamma^{2}-1\right)\right]
\end{gathered}
$$

Domestic profits increase as the quota becomes more restrictive, since more residual demand allows the domestic firm to attain higher profit levels, while foreign profits decrease ${ }^{9}$.

Proposition 1 : The domestic firm invests less in cost reduction $\left(\widetilde{\Delta}_{1}<\right.$ $\left.\Delta^{*}\right)$ for a quota set at, or close to, the free-trade level $\left(\bar{x}=x^{*}\right)$ than under free trade. As the quota $(\bar{x})$ becomes more restrictive, $\widetilde{\Delta}_{1}$ increases.

Proof: With a quota set at the free-trade level, i.e., with $\bar{x}=x^{*}$, the resulting investment in cost-reducing tecnology $\left(\hat{\Delta}_{1}\right)$ will be below the free trade value $\left(\Delta^{*}\right)$ :

$$
\hat{\Delta}_{1}\left(\bar{x}=x^{*}\right)=\frac{\left(2-\gamma^{2}\right)^{2}(a-c)}{D(\gamma)}<\frac{2\left(2-\gamma^{2}\right)(a-c)}{D(\gamma)}=\Delta^{*} .
$$

$\hat{\Delta}_{1}$ is decreasing in $\bar{x}$ since $\hat{\Delta}_{1}=a-c-\gamma \bar{x}$.

PROPOSITION $2:$ The foreign firm invests more in cost reduction $\left(\widetilde{\Delta}_{2}>\right.$ $\Delta^{*}$ ) than under free-trade when a quota is set at, or close to, the freetrade level. Investment in $R \& D$ decreases with the restrictiveness of the quota. If the quota is sufficiently restrictive (in particular for $\bar{x}<\Delta^{*}$ ), the foreign firm invests less than under free trade.

Proof: With a quota set at the free-trade level, i.e., with $\bar{x}=x^{*}$, the resulting investment in cost-reducing technology $\left(\hat{\Delta}_{2}\right)$ will be above the free-trade level $\left(\Delta^{*}\right): \hat{\Delta}_{2}\left(\bar{x}=x^{*}\right)=x^{*}>\Delta^{*}($ from $(6))$. Since $\hat{\Delta}_{2}=\bar{x}$,

9. this is easily shown. 
this implies that, for levels of restriction less than free trade level of innovation $\bar{x}<\Delta^{*}$, the foreign firm will invest less than it does under free trade.

When a restraint is set at the free-trade level of imports the foreign firm chooses to innovate more and the domestic firm less ${ }^{10}$. The results under price competition differ from those obtained under Cournot competition, where both the domestic and the foreign firm lower their R\&D expenditures after the imposition of the quota (REITZES [1991]). The reason is that, under Cournot competition, foreign $\mathrm{R} \& \mathrm{D}$ spending has a positive indirect (strategic) effect on foreign firm's profits, while under Bertrand competition this effect is a negative one. Under price competition, a foreign firm's increase in $R \& D$ spending leads the domestic firm to lower its price, which in turn results in lower price and profits for the foreign firm. The foreign firm thus "underinvests" in $R \& D$ when there is free trade. Once a quota is imposed this strategic effect vanishes, since the domestic price no longer depends on foreign firm's choice of R\&D spending. Consequently, more investment in cost-reducing $R \& D$ takes place in the constrained case than in the unconstrained case. The effect on the unconstrained domestic firm is just the opposite. It spends less on R\&D after the imposition of the quota because it faces less competition (since the foreign firm is now constrained).

\section{Welfare}

In this section we analyze the effect of imposing a quota on domestic welfare versus free trade. It is shown that total welfare is always the highest under free trade than under any level of quota for any degree of product differentiation.

To compute the consumer surplus, recall that preferences are quasilinear ${ }^{11}$. Hence,

$$
C S=a\left(\hat{x}_{1}+\hat{x}_{2}\right)-\frac{\hat{x}_{1}^{2}+\hat{x}_{2}^{2}+2 \gamma \hat{x}_{1} \hat{x}_{2}}{2}-\hat{p}_{1} \hat{x}_{1}-\hat{p}_{2} \hat{x}_{2}
$$

Using (17)-(20) and simplifying, we get:

$$
C S=\frac{1}{2}\left[(a-c)^{2}+\left(1-\gamma^{2}\right) \bar{x}^{2}\right] .
$$

Total domestic welfare $(T W)$ is defined as the sum of the consumer surplus and the domestic firm's profits:

$$
T W=C S+\hat{\pi}_{1} \text {. }
$$

10. It should at this point be stressed that both propositions 1 and 2 also hold under the simultaneous move game.

11. See footnote 2 . 
Then, using (21) we get

$$
T W=(a-c)^{2}-\gamma \bar{x}(a-c)+\frac{\bar{x}^{2}}{2} .
$$

It can easily be seen that total domestic welfare under the quota initially decreases with $\bar{x}$, it reaches a minimum at $\bar{x}=\gamma(a-c)$ and then increases with $\bar{x}$. Hence, it reaches its maximum either at $\bar{x}=0$ or at $\bar{x}=x^{*}$ depending on the degree of product substitutability.

Figure 4 represents total welfare as a function of the product differentiation parameter, $\gamma^{12} . T W_{F}$ represents total welfare under free trade. $T W(\bar{x}=0)$ represents total welfare when the foreign firm is shut out of the market, which is given by $(a-c)^{2}$ and is independent of the degree of product differentiation. $T W\left(\bar{x}=x^{*}\right)$ represents welfare when the quota is set at the free-trade level of production.

FiguRE 4

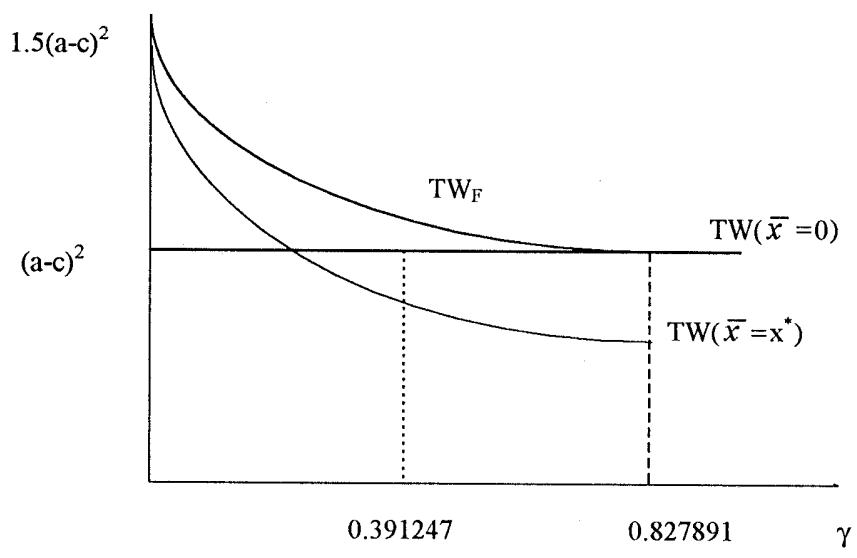

Total welfare under free trade is $T W_{F}=C S_{F}+\pi^{*}$, where (see footnote 2)

$$
C S_{F}=2 a x^{*}-x^{* 2}-\gamma x^{* 2}-2 p^{*} x^{*}
$$

Using (6)-(8) and simplifying, we get:

$$
T W_{F}=\frac{24+16 \gamma-24 \gamma^{2}-8 \gamma^{3}+8 \gamma^{4}+\gamma^{5}-\gamma^{6}}{\left(4+4 \gamma-4 \gamma^{2}-\gamma^{3}+\gamma^{4}\right)^{2}}(a-c)^{2}
$$

In figure 4, total domestic welfare under free trade, $T W_{F}$, is represented by the upper line. Free trade leads to a higher domestic welfare than the optimal restriction for any value of the product substitutability parameter.

12. We will restrict our attention to $\gamma<0.827891$ since this condition is necessary to guarantee $\pi_{i}^{*} \geq 0$. 
Welfare is higher under free trade. This result is true for any degree of product differentiation. The reason is that quotas act as collusion facilitating practices. As a result, consumers pay much higher prices after the imposition of the quota, and thus consumer surplus is reduced substantially. The increase in domestic firm's profits, on the other hand, is not enough to compensate for the loss in the consumer surplus. This constitutes a very strong result against the imposition of quotas. However, if a quota has to be imposed, then the size of the restriction depends on the degree of substitutability between the two goods. For sufficiently differentiated goods, $\gamma<0.391247$, the quota should be set at the free trade level of output of $\bar{x}=x^{*}$. However, when the goods are close substitutes, $\gamma>0.391247$, it should be set at $\bar{x}=0$. This is along the line of the import substitution argument: closer substitutes to domestic goods are subject to tighter import restrictions. Note, the imposition of a quantity restriction (KRISHNA [1989]) facilitates collusion between the foreign and the domestic firm. Thus, it is reasonable to assume that a foreign country has the incentives not to in-fact retaliate to the quantity restriction as it makes a higher level of profits.

\section{Conclusions}

This paper shows that, under price competition, when a quantity constraint is imposed at the free trade level of production, or close to it, the foreign firm increases its expenditures on R\&D. The domestic firm, however, chooses to spend less than in the absence of that quantity restriction. These results partially differ from the Cournot competition case analyzed by ReITZES [1991] where both the foreign and domestic firm lower their R\&D expenditures. Under price competition, foreign investment in $R \& D$ has a negative strategic effect on foreign firm's profits: more investment in R\&D by the foreign firm makes the domestic firm lower its own price, which in turn results in lower price and profit levels for the foreign firm. With the introduction of a quota this negative effect disappears and foreign firm's investment in R\&D necessarily increases. Under Cournot competition, the strategic effect has the opposite sign, which explains this reversal in results for the foreign firm.

We further show that, as the quota becomes more restrictive, the domestic firm increases its spending on $R \& D$ while the foreign firm decreases it. In this sense, results in line with the "infant-industry" argument in favor of protection can be achieved with a quota but only if it is sufficiently restrictive. As in the "infant industry" argument, industries producing close substitutes to potential imports desire protection. Finally, it is shown that domestic welfare is always lower in the presence of a quantity restriction than under free trade. This result is independent of the degree of product differentiation and the level of the quantity restriction. This constitutes a strong argument against the imposition of quantity restrictions, such as quotas and VERs. The empirical evidence from countries that used this 
type of regulatory policy clearly does not lend support to the infant industry protection argument either.

\section{- References}

Bester, H., Petrakis, E. (1993). - "The Incentive for Cost Reduction in a Differentiated Industry”, International Journal of Industrial Organization, 11, pp. 519-34.

Brander, J., Spencer, B. (1985). - "Export Subsidies and International Market Share Rivalry", Journal of International Economics, 16, pp. 227-42.

Corneo, G. (1995). - "National Wage Bargaining in an Internationally Integrated Product Market", European Journal of Political Economy, 11, 3.

Deneckere, R., Kovenock, D. (1992). - "Price Leadership", Review of Economic Studies, 59, pp. 143-62.

Dixit, A. (1979). - "A Model of Oligopoly Suggesting a Theory of Entry Barriers", Bell Journal of Economics, 10.

Eaton, J., Grossman, G. (1986). - "Optimal Trade and Industrial Policy under Oligopoly”, Quarterly Journal of Economics, 101, pp. 383-406.

Furth, D., Kovenock, D. (1993). - "Price Leadership in a Duopoly with Capacity Constraints and Product Differentiation", Journal of Economics, 57, 1, pp. 1-35.

HARris, R. (1985). - "Why Voluntary Export Restraints Are Voluntary?", Canadian Journal of Economics, 18, pp. 799-809.

Kujal, P. (1996). - "The Impact of Regulatory Control on Industry Structure: A Study of the Car and Scooter Industry in India”, Working Paper 96-15, Universidad. Carlos III de Madrid.

KrISHNA, K. (1989). - "Trade Restrictions and Facilitating Practices", Journal of International Economics, 26, pp. 251-70.

Reitzes, J. D. (1991). - "The Impact of Quotas and Tariffs on Strategic R\&D Behavior", International Economic Review, 32(4).

Syropoulos, C. (1996). - "Nontarriff Trade Controls and Leader Follower Relations in International Competition”, Economica, 63, pp. 633-48. 